\title{
Editors play down risk
}

The Daily Post's editor, Jale Moala, and news editor, Mesake Koroi, disagree with the view that the sale of the newspaper is a threat to media independence. In this interview, they make a rare statement, defending the Daily Post's independence.

\section{By MITHLESHNI GURDAYAL}

THE BUY OUT of one of Fiji's two daily newspapers, the Daily Post, by the Fiji Islands Government has been reported as a threat to media independence. But the paper's editor disagrees. Opposition political parties and media organisations have seen this sale as a threat to "media freedom". Many critics and nongovernment organisations have said that Government has acted "with cunning" in choosing this time to invest in the newspaper. Many members of the public feel that those who made this move have personal motives - perhaps to use the paper to come back this year to govern.

However, the Fiji Media Council sees the move as a serious threat to media independence and it urges the Government to divest itself of its shares as soon as possible by placing them on the Suva Stock Exchange. Other critics have also expressed dismay over the sale.

But the editorial man who runs the paper doesn't share their view. Editor Jale Moala is "happy" that Government now owns 46 per cent of the shares in the paper.

"I am happy about the deal because it really doesn't make any difference," says Moala. He told Wansolwara that the Government was just trying to help the paper by bringing in improvements. He says that as far as the "timing" of the purchase was concerned, it was just the right time when the shares were for sale.

"Many organisations were interested to buy the shares like C J Patel and Co 
Ltd and so Government came in just like any buyer," Moala says. "I don't see any personal gain or motive for any sort of political gains."

His colleague, news editor and political columnist Mesake Koroi, says that all this talk about "media freedom" being at risk is just a comment and carries no weight at all. "What is media freedom and how free is our press and which media organisation is free to speak out the truth?" he asks. Koroi says that people usually talk about Government interfering with the press but never wait a minute to think about the advertisers who finance the industry.

"We have big business houses pouring in large sums of money in our paper but do they sometimes interfere or try showing their ownership?" says Koroi. "We can't go against the advertisers. I am sure we can't write anything negative about their products or can we?"

He said that all Government was asking the media was to be "fair" with their journalism.

"I as a news editor want to act fairly with the Government but report the truth." He said that in no cirumstances would the paper's editorial policy change but it would try to accommodate accurate and fair reporting.

"I am not under any pressure and am free to publish what I want to," he says. "We always feel that our media industry is free but no it's not. In practice, media is not pure and free."

A recent Daily Post editorial criticised its rival, the Fiji Times, for not giving the paper a "fair deal" in reports of the buy out.

Most USP students and members of the public interviewed by Wansolwara said a Government-owned newspaper was never free.

Sherrel Mudaliar, a BA student, said a Government newspaper was "sluggish" and carried no weight.

"I don't read the paper because it's now a carrier of Government propaganda," she said.

Maria Sham, a schoolteacher, said: "Maybe now we can't see the Government censorship but it's all happening in a very subtle way and I know that editors must be under great pressure."

Mithleshni Gurdayal is a fourth-year journalism and development studies student at the University of the South Pacific carrying out research on media. This article is extracted from a report in the student training newspaper Wansolwara, Vol 4 No 1, April, 1999. 